DOE/EA-1194

\title{
ENVIRONMENTAL ASSESSMENT \\ FOR THE EXPANSION AND OPERATION OF THE CENTRAL SHOPS BORROW PIT AT THE SAVANNAH RIVER SITE
}

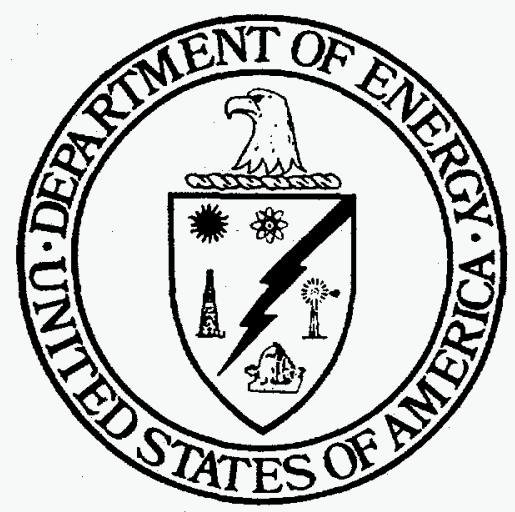

MARCH 1997

U. S. DEPARTMENT OF ENERGY

SAVANNAH RIVER OPERATIONS OFFICE

SAVANNAH RIVER SITE 
This page is intentionally left blank 


\section{DISCLAIMER}

This report was prepared as an account of work sponsored by an agency of the United States Goverament. Neither the United States Government nor any agency thereof, nor any of their employees, makes any warranty, express or implied, or assumes any legal liability or responsibility for the accuracy, completeness, or usefulness of any information, apparatus, product, or process disclosed, or represents that its use would not infringe privately owned rights. Reference herein to any specific commercial product, process, or service by trade name, trademark, manufacturer, or otherwise does not necessarily constitute or imply its endorsement, recommendation, or favoring by the United States Government or any agency thereof. The views and opinions of authors expressed herein do not necessarily state or reflect those of the United States Government or any agency thereof. 


\section{DISCLAIMER}

Portions of this document may be illegible in electronic image products. Images are produced from the best available original document. 
TABLE OF CONTENTS

1.0 INTRODUCTION

1.1 Background

1.2 Purpose and Need for Action

2.0 PROPOSED ACTION AND ALTERNATIVES 3

2.1 Proposed Action 3

2.2 Alternatives to the Proposed Action 6

2.2.1 No Action, Cease Any Further Excavation Activities and Maintain the Subject Lands in the Present Condition

2.2.2 Construct and Operate a Single Borrow Pit at an Alternate Location on SRS

2.2.3 Construct and Operate Several Smaller Borrow Pits on SRS

2.2.4 Obtain the Needed Borrow Material from an Off-Site Source

3.0 AFFECTED ENVIRONMENT 7

3.1 Land Use

3.2 Meteorology and Climatology

3.3 Geology and Seismology 8

3.4 Hydrology 8

3.5 Ecological and Cultural Resources 9

3.6 Radiation Environment 10

$4.0 \quad$ ENVIRONMENTAL CONSEQUENCES OF THE
PROPOSED ACTION AND ALTERNATIVES

4.1 Facility Expansion 11

4.2 Facility Operation 12

4.3 Facility Closure 12

4.4 Transportation 13

4.5 Human Health Effects 13

4.6 Environmental Consequences of the Alternatives 13

4.7 Cumulative Impacts 13

5.0 REGULATORY AND PERMITTING PROVISIONS
CONSIDERED

5.1 National Environmental Policy Act of 1969 as amended 14

5.2 South Carolina Stormwater Management and Sediment Reduction

6.0 AGENCIES AND PERSONS CONSULTED 14

$\begin{array}{lll}7.0 & \text { REFERENCES } & 15\end{array}$ 


\section{LIST OF FIGURES}

Figure 1-1. Location of Central Shops Borrow Pit at the

Figure 2-1. Specific location of the Central Shops Borrow Pit and the surrounding area at the Savannah River Site, South Carolina.

Figure 2-2. Preliminary conceptual design layout of the Central Shops Borrow Pit at the Savannah River Site, South Carolina. 


\subsection{INTRODUCTION}

The Department of Energy (DOE) prepared this Environmental Assessment (EA) to assess the potential environmental impacts of the proposed expansion and operation of an existing borrow pit at the Savannah River Site (SRS), located near Aiken, South Carolina (Figure 1-1). A borrow pit is defined as "an excavated area where material has been dug for use as fill at another location" (Woolf, 1973). The proposed action would entail the areal enlargement, continued operation, and eventual close-out of the established facility known as the Central Shops Borrow Pit. Operations at SRS supporting waste site closure and the construction and maintenance of site facilities and infrastructure require readily available suitable soil for use as fill material. With the recent depletion of the other existing on-site sources for such material, DOE proposes to expand the existing facility.

This document was prepared in compliance with the National Environmental Policy Act (NEPA) of 1969, as amended; the requirements of the Council on Environmental Quality Regulations for Implementing NEPA (40 CFR Parts 1500-1508); and the DOE Regulations for implementing NEPA (10 CFR Part 1021). NEPA requires the assessment of environmental consequences of Federal actions that may affect the quality of the human environment. Based on the potential for impacts described herein, DOE will either publish a Finding of No Significant Impact or prepare an Environmental Impact Statement (EIS).

\subsection{Background}

Both planned and potential future activities at SRS involve the use of suitable soil for structural backfill, subbase, and general fill material for a variety of site operations, maintenance, and new construction. Although largely used for construction of site facilities (e.g., buildings, bridges, and roads), there has been an increasing need for such material for waste site closure activities (e.g., closure caps and backfill). The primary on-site source of suitable soils has been the Burma Road Borrow Pit. However, suitable material at that facility is nearly exhausted. Extension of the facility is not feasible due to the depth of excavation that would be required to access suitable soils.

A survey of SRS for the presence of suitable soil and fill material resulted in the identification of the Central Shops location. A preliminary investigation of the location revealed that a small borrow pit had been excavated in the north-central portion of the proposed facility footprint in the past. Recent soil surveys of the site revealed the presence of desirable material surrounding the old borrow pit.

DOE decided to begin limited excavation at the Central Shops location to meet an existing need for fill material for the construction of closure caps for specific SRS waste sites. An SRS Site Use Permit was approved and issued for this action. As ancillary components of waste site closure actions, these limited excavation activities were covered by categorical exclusions (CXs) under DOE's NEPA procedures. However, with the depletion of the available resources at the Burma Road facility, DOE identified the need for suitable soils for construction and maintenance activities from another site source. Construction-related excavation activities are not encompassed by a typical class of action covered by a CX. Further, there is some potential for cumulative impacts resulting from the implementation of several separate actions at the same general location. To address these issues and ensure adequate review under NEPA, DOE decided to prepare this EA. 


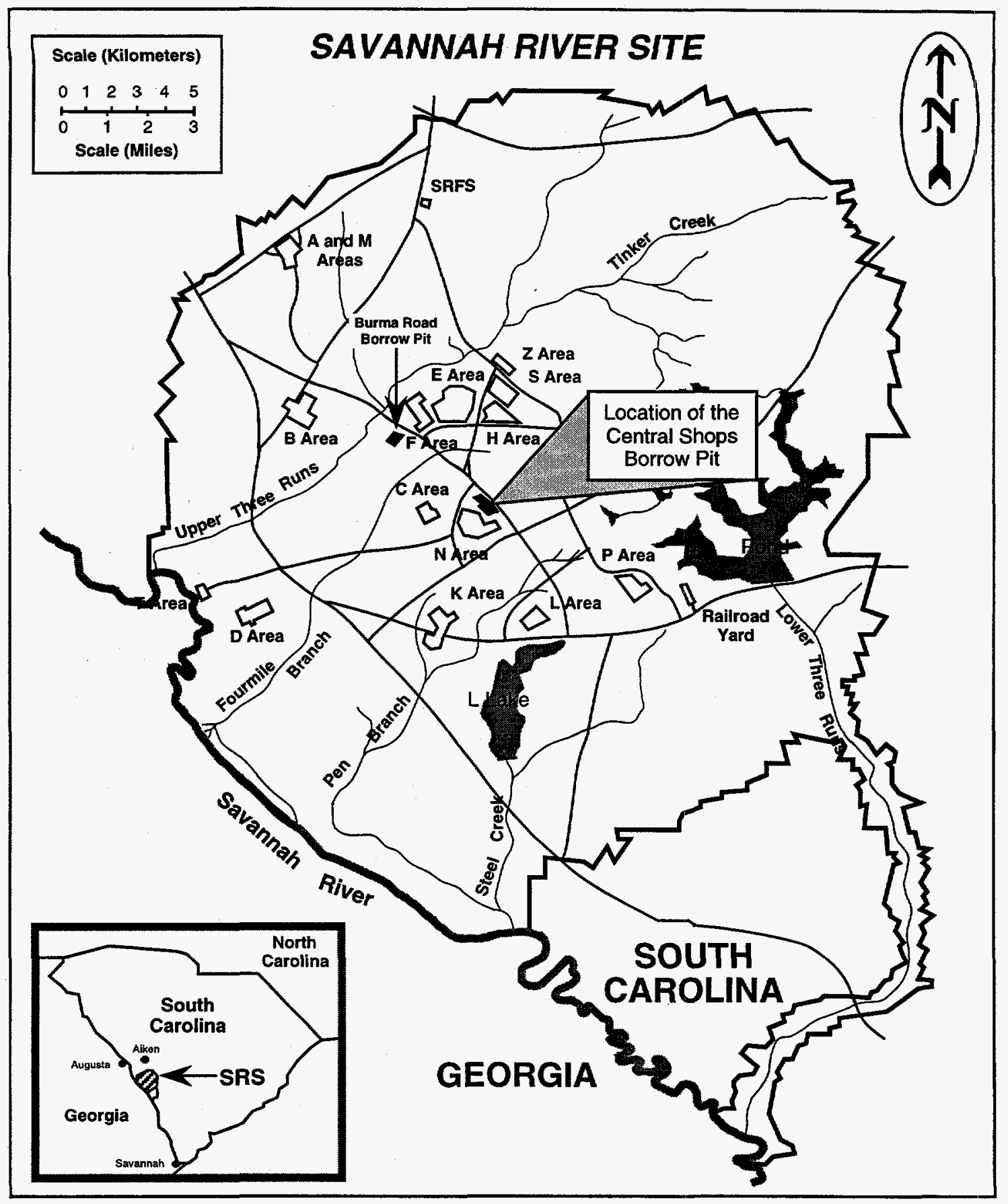

Figure 1-1. Location of the Central Shops Borrow Pit at the Savannah River Site, South Carolina. 


\subsection{Purpose and Need for Action}

The purpose of the proposed action is to provide SRS with an on-site source of suitable soils for use as fill material. DOE needs to establish a readily-available local source for these materials to support SRS waste site closure actions and site construction and maintenance activities.

\subsection{PROPOSED ACTION AND ALTERNATIVES}

\subsection{Proposed Action}

The proposed action is to expand and operate the existing Central Shops Borrow Pit. This entails three specific components: 1) construction of the expanded facility; 2) operation of the expanded facility; and 3) close-out and restoration of the site. Illustrations of the specific location and conceptual design layout of the facility are provided in Figures 2-1 and $2-2$, respectively.

The Central Shops Borrow Pit is located in the middle of SRS and is bounded by $N$ Area and SRS Roads C, 3, and A-6 (Figure 2-1). The overall footprint of the proposed expanded facility encompasses an area of approximately 35.8 hectares ( 88.4 acres). This footprint is bounded by north coordinates N61408.07 to N65573.16 and east coordinates E53400.00 to E54883.33 (Garrison, 1995)

Expansion of the existing facility would include grading/site drainage improvements and infrastructure construction. The facility's infrastructure would include the access road, the sedimentation basin, and the outfall structure (Figure 2-2). Pursuant to the implementation of the initial excavation activities associated with waste site closures, general site clearing and harvesting of merchantable timber has already been completed by the U. S. Forest Service Savannah River Forest Station (SRFS). Except in the area of the vehicle entrance, standing timber has been left around the boundaries of the expanded borrow pit footprint. This will functionally provide both a wind buffer and visual screen for the proposed facility.

The proposed action would be implemented in two phases. The first phase, encompassing an area of 24.6 hectares ( 60.8 acres), would include site preparation of the expanded excavation area (i.e., complete clearing and grading), and construction of the sedimentation basin and outfall structure and approximately one-half of the access road (Figure 2-2). The second phase, encompassing an area of 11.2 hectares ( 27.6 acres), would involve only site preparation and construction of the remaining portion of the access road. The anticipated lifetime of this facility would be 10 years.

Operational activities at the expanded borrow pit would entail the use of face excavation practices. The excavation activities would vary from approximately 1.8 meters ( 6 feet) up to approximately 12.2 meters (40 feet) in depth. Excavation operations would be accomplished by means of a single backhoe filling one or more dump trucks used for hauling the borrow material to a specific project location on site.

The proposed facility would potentially operate for a maximum of approximately 260 days during the calendar year. However, because fill materials are needed only at certain times, the facility would be closed during most of any year. Typically, only one ten-hour shift is expected to be implemented during any excavation activities for the life of the project. The initial number of site and subcontractor employees at the proposed facility would be 3 


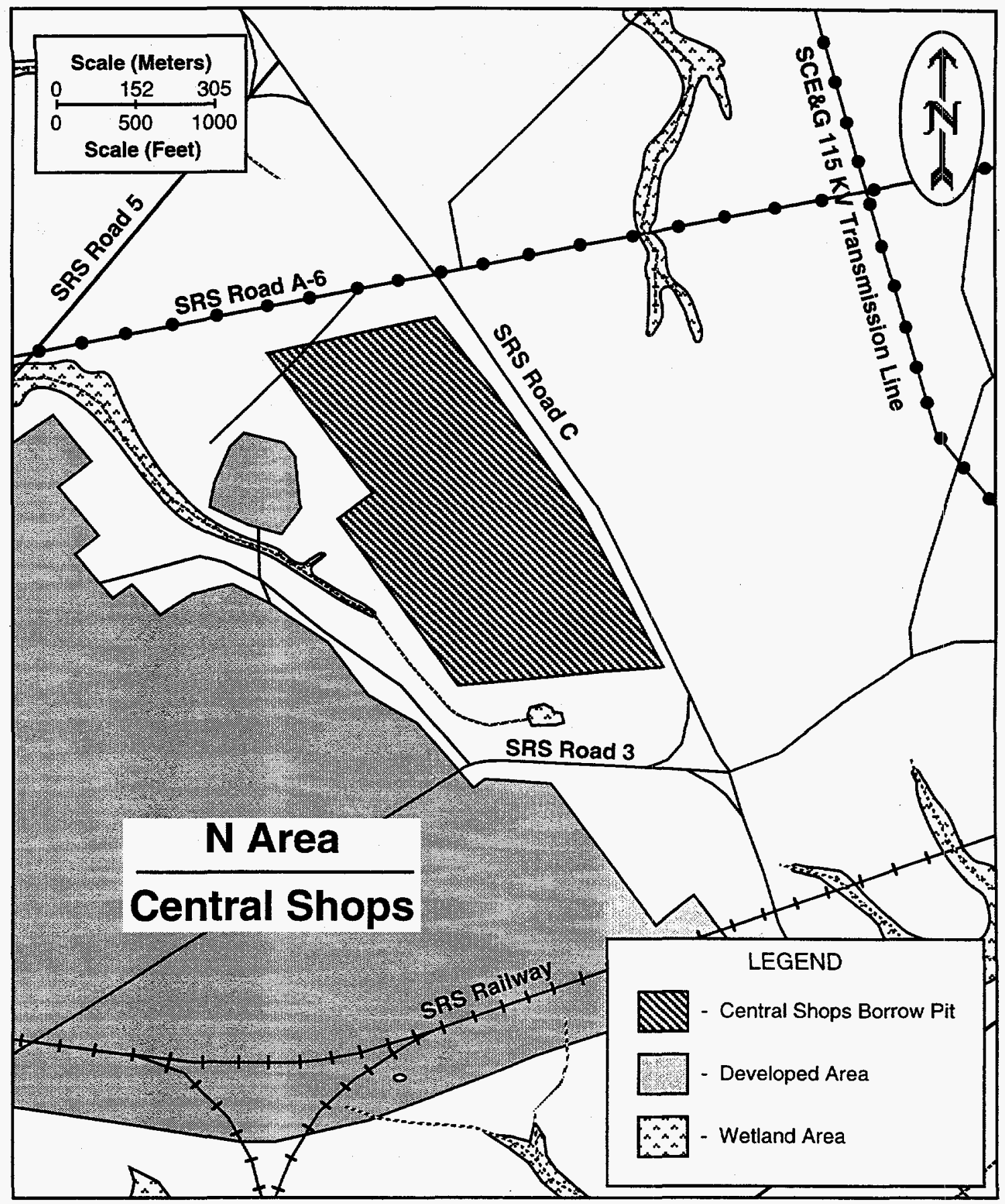

Figure 2-1. Specific location of the Central Shops Borrow Pit and the surrounding area at the Savannah River Site, South Carolina. 


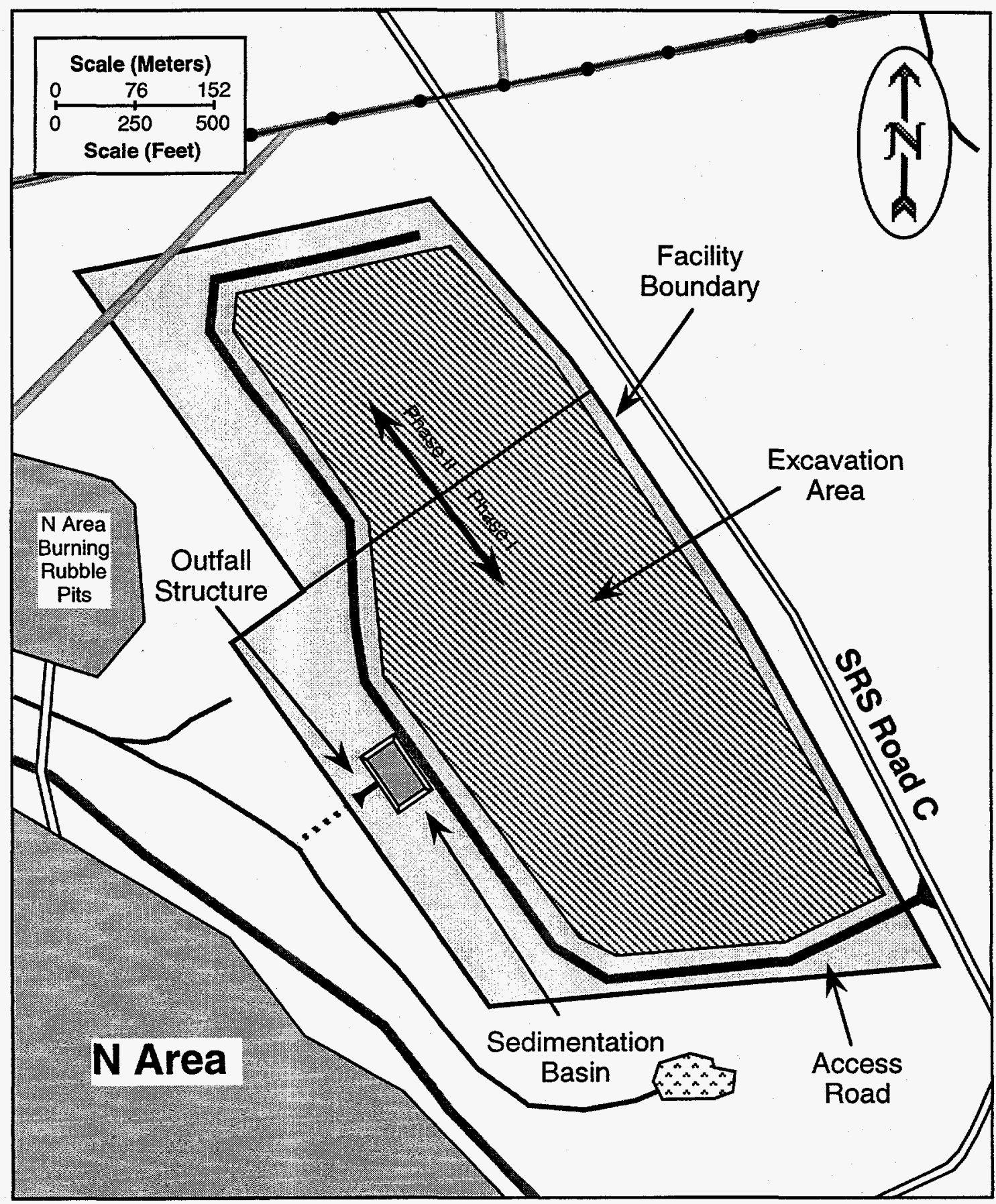

Figure 2-2. Preliminary conceptual design layout of the Central Shops Borrow Pit at the Savannah River Site, South Carolina. 
and 3, respectively. This could increase during short periods of time to a maximum of approximately 12 subcontractor employees during major excavation efforts.

No site utilities would be needed to support the subject facility. Emergency services (i.e., fire, medical and law enforcement) would be provided by SRS. The facility would only be accessible through a locked gate in order to control access. The perimeter of the facility would not be fenced.

Vehicle access to the Central Shops Borrow Pit would be by road via SRS Road C (Figures 2-1 and 2-2). Transportation of material to specific project locations would be over the existing SRS roadway system. Traffic signs would be erected on SRS Road C warning drivers of the truck traffic entering that site roadway from the proposed facility.

The proposed expanded facility would have a stormwater management system, draining into a sedimentation basin. The effluent discharging to this basin would result from storm water runoff. The access road would function as control structure to further direct the flow of stormwater runoff. This basin would be designed to contain a 25 -year storm event. Overflow from this basin would be directed out a standpipe riser through two barrel pipes to an outfall structure and concrete fan. This overflow system ultimately would be directed toward the drainage feature located parallel to the western boundary of the facility. The South Carolina Department of Health and Environmental Control (SCDHEC) has issued a stormwater management permit to the site for operation of this system.

Following termination of the excavation activities, the project site would be graded and seeded to prevent erosion from occurring. The sedimentation basin and outfall structure would be razed and the resulting debris (for example, pipes and concrete) removed for either reuse or disposal. The project site would then be allowed to re-vegetate naturally. If additional site preparation (e.g., soil enrichment or fertilization) were implemented, this acreage ultimately could be planted by SRFS with tree species for timber managennent purposes.

\subsection{Alternatives to the Proposed Action}

In accordance with NEPA regulations, DOE examined the following alternatives to the proposed action:

- No action, cease any further excavation activities and maintain the subject lands in the present condition

- $\quad$ Construct and operate a single borrow pit at an alternate location on SRS

- $\quad$ Construct and operate several smaller borrow pits on SRS

- Obtain the needed borrow material from an off-site source

\subsubsection{No Action, Cease Any Further Excavation Activities and Maintain the Subject Lands in the Present Condition}

One alternative to the proposed action is to take no action. This would consist of DOE ceasing any further excavation or borrow activities at the project location. SRS would then maintain the site in the current condition and for the current land use practices. If DOE chooses this alternative, the impacts described in Section 4 would not occur. This alternative would not enable SRS to meet the immediate need for suitable and readily available borrow material. As such, the site would not be able to complete either waste site 
closure actions or facility/infrastructure construction and maintenance in a timely or cost-effective manner.

\subsubsection{Construct and Operate a Single Borrow Pit at an Alternate Location on SRS}

Another alternative would be to implement the proposed action at a different location on SRS. Potential alternate locations were explored by assessing how these would meet the capability to provide suitable soil to support the site criteria. These alternate locations did not meet either the general siting criteria (e.g., not be near any environmentally sensitive areas, such as wetlands, floodplains, archaeological sites, or protected species habitats) or the capacity to provide sufficient borrow materials to support the site needs. The Central Shops location is the only site on SRS identified to date which collectively meets these various selection issues.

\subsubsection{Construct and Operate Several Smaller Borrow Pits on SRS}

Another alternative would be to implement the proposed action at several different smaller borrow pits on SRS. Such sites do exist within the SRS boundaries. Implementation of several smaller borrow operations would necessitate the unnecessary replication of design, construction, operation, closure activities, and environmental impacts. Although this alternative would likely be able to meet the site needs for borrow material, it would be neither cost effective or operationally efficient.

\subsubsection{Obtain the Needed Borrow Material from an Off-Site Source}

A fourth alternative would be to obtain the needed borrow material from an off-site source. Although this option might meet the site needs, it would necessitate the purchase of fill material and increase the transportation scope of work to include an off-site component. As with the previous alternative, it would be neither cost effective or operationally efficient.

\subsection{AFFECTED ENVIRONMENT}

The SRS occupies an area of approximately 800 square kilometers (300 square miles) in southwestern South Carolina (Figure 1-1). The site borders the Savannah River for about 27 kilometers (17 miles) near Augusta, Georgia, and Aiken and Barnwell, South Carolina. SRS contains five nuclear production reactor areas, two chemical separations facilities, waste treatment, storage and disposal facilities, and various supporting facilities. The Final EIS for the Interim Management of Nuclear Materials (DOE, 1995) and the most recent socio-economic survey of the six-county SRS area of influence (HNUS, 1992) contain additional information on SRS areas and facilities, and the areas surrounding SRS.

\subsection{Land Use}

The proposed expanded borrow pit is located on a 35.8-hectare (88.4-acre) site situated to the east of $\mathrm{N}$ Area (Figure 2-1). The project site has to date only been used for borrow material excavation and timber management activities.

\subsection{Meteorology and Climatology}

The SRS region has a temperate climate with mild winters and long summers. The average annual rainfall at SRS is about 122 centimeters (48 inches) and the average wind speed in 1987-91 was 13.7 kilometers/hour (8.5 miles/hour) (Bauer et al., 1989; DOE, 1995). 
Tornadoes have been observed during every month of the year in the area encompassing SRS, but occur most frequently in the spring (Bauer et al., 1989). Only a few instances of slight to moderate tornado damage to support facilities have been documented for the site to date. Bauer et al.(1989) contains additional information on SRS meteorology and climatology. The general meteorological and climatological data for SRS would be representative of that for the borrow pit location.

\subsection{Geology and Seismology}

The SRS is located in the Aiken Plateau physiographic region of the upper Atlantic Coastal Plain approximately 40 kilometers ( 25 miles) southeast of the Fall Line which separates the Piedmont Plateau from the Atlantic Coastal Plain. The topographic surface of the coastal plain slopes gently seaward and is underlain by a wedge of seaward-dipping unconsolidated and semiconsolidated sediments from the Fall Line to the coast of South Carolina. The Atlantic Coastal Plain tectonic province in which SRS is located is characterized by generally low seismic activity that is expected to remain subdued (Haselow et al., 1989).

The borrow pit project site is relatively level, varying in elevation from approximately 104 meters (340 feet) mean sea level (msl) at the northeastern corner of the expanded facility boundary down to an approximate elevation of 85 meters (280 feet) msl at the central western facility boundary (USGS, 1988).

The soil types within the proposed project location are dominated by Dothan and Fuquay sands. Both of these soil associations consist of well drained, slowly to moderately permeable soils that typically have a 0 to 10 percent slope. These soils are typically associated with broad ridgetops and fairly smooth side slopes (Rogers, 1990).

No faults are located within the proposed project area. The most active seismic zones in the southeastern United States are all located over 160 kilometers (100 miles) away from the site. A recent EIS (DOE, 1995) contains information on SRS fault location and earthquake occurrences.

\subsection{Hydrology}

The Savannah River forms the western boundary of SRS and receives drainage from five major tributaries on the site: Upper Three Runs, Fourmile Branch, Pen Branch, Steel Creek, and Lower Three Runs. These tributaries receive varying types of wastewater discharges from plant processes and sanitary treatment systems, all of which are permitted through the National Pollutant Discharge Elimination System (NPDES). On SRS, various plant processes also require the pumping of Savannah River water and/or on-site groundwater. A recent EIS (DOE, 1995) contains information on groundwater systems on SRS and in the surrounding region.

The proposed facility site is located on the western portion of a ridgetop draining to the southwest into a tributary of the Fourmile Branch basin (USGS, 1988). The area proposed for development of the Central Shops Borrow Pit is located approximately 61 meters (200 feet) north and 46 meters (150 feet) east of the nearest jurisdictional wetlands boundary associated with the aforementioned drainage corridor (Figures 2-1 and 2-2). No wetlands are located on the project site (Nelson, 1996). This site is also situated approximately 1707 meters (5600 feet) south-southeast of the nearest 100-year floodplain, which is located on Fourmile Branch (NUS Corporation, 1984). 
The depth to uppermost groundwater ranges from 10 to 28 meters ( 33 to 70 feet) below grade. The direction of flow of the uppermost groundwater is to the south-southwest. The nearest domestic water well (i.e., 905-136G, Central Sanitary Wastewater Treatment Facility) is located approximately 3.8 kilometers (2.4 miles) to the west-northwest in a lateral gradient to the proposed project site (Arnett and Mamatey, 1996; Arnett, 1996; Haselow et al., 1989).

Although no groundwater contamination exists at the project location, a small area of localized lead contamination has been found in the uppermost groundwater beneath the $\mathrm{N}$ Area burning rubble pit. Located to the west of the Central Shops Borrow Pit site (Figure 2-2), this burning rubble pit has produced lead levels in the uppermost water table (which is not used for potable water) which are above the drinking water standards. The only other nearby monitoring wells, located at the $\mathrm{N}$ Area burning rubble pit south, did not have any constituents which were detectable above the aforementioned drinking water standards. Further downgradient from both of these burning rubble pits and the Central Shops Borrow Pit project site, the lead levels present were not even detectable at two sampling stations located downstream within the Fourmile Branch drainage corridor (Arnett and Mamatey, 1996).

\subsection{Ecological and Cultural Resources}

Since 1951, when the U.S. Government acquired SRS, natural resource management practices and natural succession outside of the construction and operation areas at SRS have resulted in increased ecological complexity and diversity of the site. Forested areas support a diversity of wildlife habitats that are restricted from public use. Forest management practices include controlled burning, harvesting of mature trees, and reforesting. Wildlife management includes control of white-tailed deer (Odocoileous virginianus) and wild swine (Sus scrofa) populations through supervised hunts. The SRS, which was designated as the first National Environmental Research Park (NERP) in 1972, is one of the most extensively-studied environments in this country. Wike et al. (1994) contains additional information on the biotic characteristics of SRS.

Six species on SRS are afforded protection by the Federal government under the Endangered Species Act of 1973. These are the bald eagle (Haliaeetus leucocephalus), wood stork (Mycteria americana), red-cockaded woodpecker (Picoides borealis), American alligator (Alligator mississippiensis), shortnose sturgeon (Acipenser brevirostrum), and smooth purple coneflower (Echinacea laevigata). None of these species are known to occur on or near the proposed facility location (Wike et al., 1994; Garrison, 1995; LeMaster, 1997).

The location for the proposed expanded borrow pit facility is on a site which has been recently clearcut. Prior to being clearcut, the site was composed of two primary habitat types. Most ( 50.4 percent) of the site was occupied by a planted pine forest dominated by 7.6-10.7 meter (25-35 foot) tall slash pine (Pinus elliottii), with a thick mid-story hardwood component. Dominant woody species within the midstory and shrub layer included southern red oak (Quercus falcata), water oak (Q. nigra), willow oak (Q. phellos), sassafras (Sassafras albidum), cherry (Prunus serotina), persimmon (Diospyros virginiana), sweetgum (Liquidambar styraciflua), wild plum ( $\underline{\mathrm{P}}$. americana), smooth sumac (Rhus glabra), and hickory (Carya spp.). The ground was covered by a moderately thick layer of pine duff, with a dense herbaceous cover dominated by poison ivy (Toxicodendron radicans) and muscadine (Vitis rotundifolia). The second community was an oldfield habitat dominated by slash pine and hardwood seedlings and herbaceous vegetation. The hardwood seedlings were comparable to those found in the older pine community's midstory area. Herbaceous species dominating the ground layer were dog fennel 
(Eupatorium spp.), bahia grass (Paspalum notatum), and morning glory (Ipomoea trichocarpa). Historically, this site have been used for timber production since the acquisition of the property by the Federal government in the early 1950s. A third small habitat type, encompassing approximately 0.4 hectare $(1.0$ acre) of an old home site, was dominated by mature hardwoods has been left standing.

A number of wildlife species are present in and around the general area of the proposed project location. The species composition is comparable to similar habitats types elsewhere on SRS. Comprehensive listings of wildlife species can be found in Wike et al. (1994).

The management and utilization of forests, soils, watersheds, and wildlife at SRS are described in the SRS Natural Resources Management Plan (DOE, 1991) and defined under the terms of a Memorandum of Agreement between DOE Savannah River Operations Office (DOE-SR), SRFS, the Natural Resources Conservation Service, and Westinghouse Savannah River Company. DOE-SR uses this Memorandum of Agreement to define the roles and responsibilities of the various agencies and organizations in the management of natural resources on SRS.

Most of the proposed project location is situated within the medium or Type II archaeological sensitivity zone for SRS. The eastern third of the site is within the lowest or Type III archaeological sensitivity zone (SRARP, 1989). The areas specifically proposed for development have been reviewed by the University of South Carolina's Savannah River Archaeological Research Program (SRARP). No complex archaeological or potential National Register of Historic Places eligible sites were identified within the proposed project location (Garrison, 1995). Cultural resources at SRS are managed under the terms of a Programmatic Memorandum of Agreement among DOE-SR, the South Carolina State Historic Preservation Officer, and the Advisory Council on Historic Preservation. DOE-SR uses this Programmatic Memorandum of Agreement to identify cultural resources, assess these in terms of National Register eligibility, and develop mitigation plans for affected resources in consultation with the South Carolina State Historic Preservation Officer. DOE-SR would comply with the stipulations of the Programmatic Memorandum of Agreement for all activities related to the proposed Central Shops Borrow Pit.

\subsection{Radiation Environment}

A person residing in the Central Savannah River Area (within 80 kilometers or 50 miles of SRS) receives an average annual radiation dose of about $360 \mathrm{mrem}$; SRS contributes less than 0.1 percent of that total. Natural radiation sources contribute about 300 mrem, medical exposures contribute about $53 \mathrm{mrem}$, and consumer products contribute aboult 10 mrem. The most recent SRS annual environmental report (Arnett and Mamatey, 1996) contains more information on the radiation environment.

Previous work at the proposed project site did not involve either the handling of or exposure from radioactive materials. Based on the results of five Thermoluminescent Dosimeter air monitoring stations located in nearby $\mathrm{N}$ Area, the average yearly exposure of gamma radiation is $149.67 \mathrm{mR}$ (one $\mathrm{mR}$ is approximately equal to one mrem). This amount is less than the average yearly exposure for population centers surrounding SRS (Arnett, 1995). 


\subsection{ENVIRONMENTAL CONSEQUENCES OF THE PROPOSED ACTION AND ALTERNATIVES}

\subsection{Facility Expansion}

The total undeveloped area cleared for the Central Shops Borrow Pit encompasses approximately 35.8 hectares ( 88.4 acres). At present, 96 percent $(75,000$ hectares or 185,325 acres) of SRS lands are undeveloped (Wike et al., 1994). Therefore, the percent of site lands proposed for use by this action would be minimal. The cleared area included 18 hectares (44.6 acres) of pine forest habitat. At present, 69 percent $(54,000$ hectares or 133,434 acres) of SRS is occupied by pine-dominated forested habitat (Workman and McLeod, 1990). The pine forest portion of the project site represents less than 0.04 percent of the site's pine stands. Further use of the location for timber management would be eliminated during the life of the subject facility. The merchantable timber formerly standing on the proposed project site has already been sold by SRFS to an off-site commercial firm, harvested by that firm, and removed from the property.

Direct and indirect socioeconomic impacts of the proposed borrow pit expansion construction workforce of 15-20 individuals would be negligible when compared to the present total SRS employment of approximately 15,000 people. The workforce would likely be derived from the ranks of on-site and local subcontractor construction companies. No measurable impact on the local economy would be expected from the proposed action.

The clearing of the project site has limited the use of the lands by wildlife species. Some of the small, less mobile species of mammals, reptiles and amphibians would have possibly been physically harmed or killed by the logging and earth-moving equipment. However, most species of mammals and birds which inhabited or used the project area would have been largely displaced by the land clearing, but probably not either injured or killed. Those animals displaced by construction into adjacent or marginal habitats may either die or experience reduced reproduction. The net result would be a lower quality habitat being available and therefore fewer individual animals being present.

As part of the SRS Site Use application review process, the project site was evaluated for the documented presence of any endangered, threatened, or sensitive species prior to clearing. No protected species were identified in or near the proposed project site during either previous site surveys or the aforementioned Site Use process (Wike et al., 1994; Garrison, 1995; LeMaster, 1997). The present clearcut condition of the project site would not be suitable for any of the Federally-protected species known to occur on SRS. Therefore, the proposed borrow pit expansion would not be likely to adversely affect any Federally-protected species.

An archaeological survey was conducted at the proposed project location. No sites were identified and/or defined during this survey which contained any archaeological deposits intact enough to qualify them as significant resources (Garrison, 1995). Therefore, no substantially adverse impacts to known cultural resources would result from the construction of the proposed borrow pit expansion (SRARP, 1989; Garrison, 1995).

Expansion of the borrow pit would not impact wetlands or floodplains. No components of the proposed action would be constructed in either of these environmentally sensitive habitats. The erosional or sedimentation impacts of any surface runoff resulting from extreme storm events during construction activities would be contained by silt fences and the berm formed by the access road along the entire southern, western, and northern borders of the site. In addition, best management practices and standard 
erosion/sedimentation control measures would be used during construction of the proposed facility.

The proposed infrastructure construction would generate minor amounts of building material debris. These waste streams would be disposed of at the municipal solid waste landfill currently being used by SRS. Because the proposed project location is previously undeveloped, no contaminated soils or waste sites are expected to be encountered during construction.

Air quality effects associated with the expansion of the Central Shops Borrow Pit would be the result of equipment use and soil disturbance. Diesel operated equipment (i.e., trucks, backhoes, graders) would be used for grading and in the performance of other routine construction activities. The operation of this type of equipment does not require an air quality permit from SCDHEC. A variety of methods (e.g., tillage, irrigation, barriers, and calcium chloride application) would be implemented to prevent blowing and movement of dust from exposed soil surfaces, reduce on- and off-site impacts, health hazards, and improve traffic safety.

\subsection{Facility Operation}

The operation of the Central Shops Borrow Pit would employ a total of six workers at startup. This would increase to as many as 15 total workers (i.e., combined site and subcontractor employees) for short periods during major excavation projects. No measurable socioeconomic impacts would be expected as a result from this portion of the proposed action.

No surface water or groundwater would be used during operation of the proposed facility. Stormwater runoff from the cleared areas would drain into the sedimentation basin. The capacity of the basin would be designed to contain a 25 -year storm event as required in the SCDHEC permit. Areas disturbed by immediate excavation activities would be re-stabilized as soon as possible to minimize erosional and sedimentation impacts.

Because of the localized nature of each excavation effort, no negative impacts would be expected to affect any environmentally sensitive areas or protected species. Because the site would not be enclosed by a perimeter fence, some limited use of the facility lands by local wildlife species would be realized during the active life of the borrow pit. Although none are expected to be encountered, any cultural or archaeological resources discovered during excavation activities would be reported to SRARP for evaluation and potential recovery.

During normal operations, no hazardous chemicals would be used at the proposed facility. Any spills or leaks (e.g., fuel, hydraulic fluid, and coolant from excavation vehicles) occurring during facility operations would be cleaned up in accordance with site procedures and protocols.

Air emissions from excavation operations would be generated by diesel operated equipment (i.e., trucks and backhoes). Emissions from this source would be expected to have only minimal impacts to local air quality.

\subsection{Facility Closure}

Upon termination of excavation activities at the Central Shops Borrow Pit, the facility lands would be graded and seeded. The facility infrastructure would be removed. Over time, the site would be expected to re-vegetate naturally. In two to three years, it would be further 
expected that the site would be occupied by an oldfield type of floral habitat. During the same period, additional wildlife species would be reestablished in the former borrow pit location. As noted in Section 2.1, following additional preparation, the project site could ultimately be replanted for timber management purposes.

\subsection{Transportation}

Construction of the expanded borrow pit would create a small, short-term increase in traffic flow along SRS Road C as a result of the movement of equipment and materials. These impacts are expected to be minimal.

Based on the current traffic volume using SRS Road C, traffic associated with operations at the Central Shops Borrow Pit would result in an increase of less than seven percent, even during major excavation projects. The current traffic volume (i.e., 690 vehicles per day) is considerably below the design maximum capacity for that road of in excess of 1,000 vehicles per hour. In addition, most (approximately 75 percent) of the SRS traffic volume along this site road is during the morning and evening shift changes. Most of the truck traffic hauling fill material from the Central Shops Borrow Pit would not be present at those periods of peak traffic flow. All truck traffic traveling to and from the proposed facility would be during daylight hours. This would further reduce the potential for accidents associated with this increase in traffic volume.

\subsection{Human Health Effects}

The Occupational Safety and Health Act (OSHA) regulations (29 CFR Part 1910) require that employers comply with safety and health standards set by the act to provide each employee with a worksite that is free from recognized hazards that are likely to cause death or serious injury. Personal protective clothing and equipment would be used as appropriate. Therefore, human health impacts would be minimal.

\subsection{Environmental Consequences of the Alternatives}

The no-action alternative would have none of the potential or expected impacts associated with the proposed action. The cleared land would allowed to re-vegetate naturally. The lack of available borrow material would limit the abilities of the site to implement waste site closures, and construction and maintenance activities. Siting the borrow pit at another SRS location would have similar, but potentially larger impacts than the proposed action. Since no other location on SRS has comparable amounts of available fill material, siting the proposed action at another location would also result in less material being available for use on site. The alternative to build several smaller borrow pits would result in smaller local impacts but to more locations on SRS overall. This would also result in the need to develop duplicate infrastructure at each individual excavation site. The fourth alternative to obtain the suitable fill material from off-site sources would result in only minimal increases to on-site and off-site traffic volume. None of the other on-site environmental impacts would be realized.

\subsection{Cumulative Impacts}

The principal cumulative impacts from the proposed action would be those effects associated with the loss of less than 0.03 percent of forested lands encompassed by the entire SRS. The site lands available for timber management would be reduced by less than 0.01 percent during the life of the project. There would be no measurable impact on the local economy as a result of the proposed action. No additional adverse impacts to either site surface or groundwater quality would be expected from the expansion and operation of 
the Central Shops Borrow Pit. A temporary loss of less than 0.05 percent of the available wildlife habitat on SRS would result with the expansion of the proposed facility. The proposed action would have no additional adverse impacts on threatened and endangered species, cultural resources, floodplain, or wetlands on SRS. Additional impacts to the local air quality would be negligible. The proposed action would not pose any additional potential problems for either public health or safety. There would be no change in the latent fatal cancers within the region as a result of the proposed action. Any increases in site traffic accident and fatality rates would be minimal as a result of the proposed action.

\subsection{REGULATORY AND PERMITTING PROVISIONS CONSIDERED}

DOE policy is to carry out its operations in compliance with all applicable Federal, state, and local laws and regulations, as well as all DOE Orders. This section provides a discussion of the major regulatory permit programs that might be applicable to the proposed action.

\subsection{National Environmental Policy Act of 1969 as amended}

This EA has been prepared in compliance with the NEPA of 1969, as amended, and the requirements of the CEQ Regulations for Implementing NEPA (40 CFR Parts 1500-1508), and DOE Regulations (10 CFR Part 1021), and DOE Order 5440.1E. NEPA, as amended, requires "all agencies of the Federal Government" to prepare a detailed statement on the environmental effects of proposed "major Federal actions significantly affecting the quality of the human environment." This EA has been written to comply with NEPA and assess the potential environmental impacts of the expansion and operation of the Central Shops Borrow Pit at SRS.

\subsection{South Carolina Standards for Stormwater Management and Sediment Reduction}

The construction and operation of the storm water management system has been permitted in accordance with the South Carolina Regulations 72-300.

\subsection{AGENCIES AND PERSONS CONSULTED}

The U. S. Forest Service SRFS was consulted during the preparation of this EA. 


\subsection{REFERENCES}

Arnett, M. W., 1996. Savannah River Site Environmental Data for 1995. WSRC-TR-96-077, Westinghouse Savannah River Company, Savannah River Site, Aiken, South Carolina.

Arnett, M. W., and A. R. Mamatey, 1996. Savannah River Site Environmental Report for 1995. WSRC-TR-96-075, Westinghouse Savannah River Company, Savannah River Site, Aiken, South Carolina.

Bauer, L. R., D. W. Hayes, C. H. Hunter, W. L. Marter, and R. A. Moyer, 1989. Reactor Operation Environmental Information Document, Volume III: Meteorology, Surface Hydrology, Transport and Impacts (U), WSRC-89817, Westinghouse Savannah River Company, Savannah River Site, Aiken, South Carolina.

DOE (U. S. Department of Energy), 1991. Natural Resources Management Plan: Strategic Guidance for the Savannah River Site's Natural Resources Programs, Savannah River Operations Office, Aiken, South Carolina.

DOE (U. S. Department of Energy), 1995. Environmental Impact Statement for Interim Management of Nuclear Materials at the Savannah River Site, DOE/EIS-0220, Savannah River Operations Office, Aiken, South Carolina.

Garrison, R. Y., 1995. All-In-One Memorandum to Distribution List. Formally Approved Site Use Permit SU-95-34-O - SRS Borrow Pit, October 25, Facilities and Services, Westinghouse Savannah River Company, Savannah River Site, Aiken, South Carolina.

Haselow, J. S., V. Price, D. E. Stephenson, H. W. Bledsoe, and B. B. Looney, 1989. Reactor Operation Environmental Information Document, Volume I: Geology, Seismology and Subsurface Hydrology (U), WSRC-89-815, Westinghouse Savannah River Company, Savannah River Site, Aiken, South Carolina.

HNUS (Halliburton NUS Environmental Corporation), 1992. Socioeconomic Characteristics of Selected Counties and Communities Adjacent to the Savannah River Site, July 1992, Halliburton NUS Corporation, Aiken, South Carolina.

LeMaster, B., 1997, Letter to J. Mayer, Biological Assessment for the Central Shops Borrow Pit Project, January 24, U. S. Forest Service, Savannah River Forest Station, New Ellenton, South Carolina.

Nelson, E. A., 1996, All-In-One Memorandum to D. D. Smith, Central Shop Borrow Pit - Wetland Discussion, January 25, Savannah River Technology Center, Westinghouse Savannah River Company, Savannah River Site, Aiken, South Carolina.

NUS Corporation, 1984. Floodplain/Wetlands Assessment of Forest Management Activities at the Savannah River Plant, SRC-84-8010/1, October 1984, NUS Corporation, Aiken, South Carolina.

Rogers, V. A., 1990. Soil Survey of Savannah River Plant Area, Parts of Aiken, Barnwell, and Allendale Counties, South Carolina, U. S. Department of Agriculture, Soil Conservation Service, Aiken, South Carolina. 
SRARP (Savannah River Archaeological Research Program), 1989. Archaeological Resource Management Plan of the Savannah River Archaeological Research Program, Savannah River Archaeological Research Program, South Carolina Institute of Archaeology and Anthropology, University of South Carolina, Aiken, South Carolina.

USGS (U. S. Geological Survey), 1988. Savannah River Plant, Department of Energy: 1987, U. S. Geological Survey, Reston, Virginia.

Wike, L. D., R. W. Shipley, A. L. Bryan, J. A. Bowers, C. L. Cummins, B. R. del Carmen, G. P. Friday, J. E. Irwin, J. J. Mayer, E. A. Nelson, M. H. Paller, V. A. Rogers, W. L. Specht, and E. W. Wilde, 1994. SRS Ecology: Environmental Information Document, WSRC-TR-93-496, Westinghouse Savannah River Company, Savannah River Site, Aiken, South Carolina.

Woolf, H. B. (ed.), 1973. Webster's New Collegiate Dictionary. G. \& C. Merriam Company, Springfield, Massachusetts.

Workman, S. W., and K. W. McLeod, 1990. Vegetation of the Savannah River Site. SRO-NERP-19. Savannah River Ecology Laboratory, Aiken, South Carolina. 


\section{Finding of No Significant Impact for the \\ Expansion and Operation of the Central Shops Borrow Pit at the Savannah River Site}

DOE $\mid E A--1194$

Agency: $\quad$ U.S. Department of Energy

Action: $\quad$ Finding of No Significant Impact

Summary: The Department of Energy (DOE) has prepared an environmental assessment (EA) (DOE/EA-1 194) for the proposed expansion and operation of the existing Central Shops Borrow Pit at the Savannah River Site (SRS), located near Aiken, South Carolina. Based on the analyses in the EA, DOE has determined that the proposed action is not a major Federal action significantly affecting the quality of the human environment within the meaning of the National.Environmental Policy Act of 1969 (NEPA). Therefore, the preparation of an environmental impact statement (EIS) is not required, and DOE is issuing this Finding of No Significant Impact (FONSI).

\section{Public Availability:}

Copies of the EA and FONSI or further information on the DOE NEPA process are available from:

A. R. Grainger, SR NEPA Compliance Officer

Engineering and Analysis Division

Savannah River Operations Office

Bldg. 773-42A/Room 212

Aiken, South Carolina 29808

Phone/FAX: (800) 881-7292

E-mail: nepa@srs.gov

Background: Both planned and potential future activities at SRS involve the use of suitable soil for structural backfill, subbase, and general fill material for a variety of site operations, maintenance, and new construction. Although largely used for construction of site facilities, an increasing need for such material has been identified for waste site closure caps and backfill. The existing on-site facility currently serving as the primary source of suitable soils is nearly exhausted.

On-site surveys for the presence of suitable soil and fill material resulted in the identification of the Central Shops location. A preliminary investigation revealed that a small borrow pit had been excavated at some time in the past in the north-central portion of the proposed facility footprint. Recent soil surveys of the site revealed the presence of desirable material surrounding this previously-established borrow pit.

DOE decided to begin limited excavation at the location to meet an existing need for fill material for the construction of closure caps for specific SRS waste sites. An SRS Site Use Permit was approved and issued for this action. As ancillary components of waste site closure actions, these limited excavation activities were covered by categorical exclusions (CXs) under DOE's NEPA procedures. However, with the depletion of the available resources at the primary on-site facility, DOE identified the need for suitable soils for construction and maintenance activities from another site source. Construction-related excavation activities are not encompassed by a typical class of 
action covered by a CX. Further, there is some potential for cumulative impacts resulting from the implementation of several separate actions at the same general location. To address these issues and ensure adequate review under NEPA, DOE decided to prepare this EA.

Proposed Action: The proposed action would entail the areal enlargement, continued operation, and eventual close-out of the existing Central Shops Borrow Pit. This facility is located in the middle of SRS and encompasses an area of approximately 35.8 hectares ( 88.4 acres). Pursuant to the implementation of the initial excavation activities associated with waste site closures, general site clearing and harvesting of merchantable timber has already been completed.

The proposed action would be implemented in two phases. The first phase, encompassing an area of 24.6 hectares (60.8 acres), would include site preparation of the expanded excavation area (i.e., complete clearing and grading), and construction of the sedimentation basin and outfall structure and approximately one-half of the access road. The second phase, encompassing an area of 11.2 hectares (27.6 acres), would involve only site preparation and construction of the remaining portion of the access road. The anticipated lifetime of this facility would be 10 years.

Operational activities at the expanded borrow pit would entail the use of face excavation practices. Excavation operations would be accomplished by means of a single backhoe filling one or more dump trucks used for hauling the borrow material to a specific project location on site. The proposed facility would potentially operate for a maximum of approximately 260 days during the calendar year. However, because fill materials are needed only at certain times, the facility would be closed during most of any year. Typically, only one ten-hour shift is expected to be implemented during any excavation activities for the life of the project. The initial total number of both site and subcontractor employees at the proposed facility would be six. This could increase during short periods of time to a maximum of approximately 15 during major excavation efforts. No site utilities would be needed to support the subject facility. The facility would only be accessible through a locked gate in order to control access. Transportation of material to specific project locations would be over the existing SRS roadway system. The proposed expanded facility would have a stormwater management system. The South Carolina Department of Health and Environmental Control has issued a permit to the site for operation of this system.

Following termination of the excavation activities, the project site would be graded and seeded to prevent erosion from occurring. The sedimentation basin and outfall structure would be razed and the resulting debris removed for either reuse or disposal. The project site would then be allowed to re-vegetate naturally. If additional site preparation (e.g., soil enrichment or fertilization) were implemented, this acreage ultimately could be planted by DOE for timber management purposes.

Alternatives: In addition to the proposed action, DOE considered the following alternatives: (1) No Action (i.e., cease any further excavation activities and maintain the subject lands in the present condition); (2) construct and operate a single borrow pit at an alternate location on SRS; (3) construct and operate several smaller borrow pits on SRS; and (4) obtain the needed borrow material from an off-site source... The no-action alternative would not enable SRS to meet the immediate need for suitable and readily available borrow material. As such, the site would not be able to complete either waste site closure actions or facility/infrastructure construction and maintenance in a timely or cost-effective manner. Siting the borrow pit at another SRS location would have similar, but potentially larger impacts than the proposed action. Since no other location on SRS 
has comparable amounts of available fill material, siting the proposed action at another location would also result in less material being available for use on site. The alternative to build several smaller borrow pits would result in smaller local impacts but to more locations on SRS overall. This would also result in the need to develop duplicate infrastructure at each individual excavation site. The fourth alternative to obtain the suitable fill material from off-site sources would result in only minimal increases to on-site and off-site traffic volume. None of the other on-site environmental impacts would be realized.

Environmental: The principal impact resulting from the proposed action would be those effects associated with the loss of less than 0.03 percent of forested lands encompassed by the entire SRS. The site lands available for timber management would be reduced by less than 0.01 percent during the life of the project. There would be no measurable impact on the local economy as a result of the proposed action. No additional adverse impacts to either site surface or groundwater quality would be expected from the expansion and operation of the Central Shops Borrow Pit. A temporary loss of less than 0.05 percent of the available wildlife habitat on SRS would result with the expansion of the proposed facility. The proposed action would have no additional adverse impacts on threatened and endangered species, cultural resources, floodplain, or wetlands on SRS. Additional impacts to the local air quality would be negligible. The proposed action would not pose any additional potential problems for either public health or safety: There would be no change in the latent fatal cancers within the region as a result of the proposed action. Any increases in site traffic accident and fatality rates would be minimal as a result of the proposed action.

Determination: Based on the information and analyses in the EA, DOE has determined that the proposed expansion and operation of the Central Shops Borrow Pit at SRS does not constitute a major Federal action significantly affecting the quality of the human environment with the meaning of NEPA. Therefore, an EIS is not required and DOE is issuing this FONSI.

Signed in Aiken, South Carolina, this 13 day of 1997.

Mario P. Fiori

Manager

Savannah River Operations Office 